\title{
Local and landscape influence on richness of amphibian species breeding in seasonal ponds in the Spanish south- Atlantic littoral. Impact determination
}

\author{
José María Torres ${ }^{1, *}$, Ignacio Hernández ${ }^{1}$, Ricardo Reques² \\ ${ }^{1}$ Department of Biology, University of Cádiz, Pol. Río San Pedro s/n, Puerto Real (Cádiz) 11510, Spain. \\ 2 Departamento de Ecología Evolutiva, Estación Biológica de Doñana, C/ Americo Vespucio s/n, 41092 \\ Sevilla, Spain. \\ *Correspondence: Department of Biology, University of Cádiz, Pol. Río San Pedro s/n, Puerto Real (Cádiz) \\ 11510, Spain. Phone: +34 646460 336, E-mail: josemaria.torrescastillo@mail.uca.es
}

Received: 17 June 2014; returned for review: 8 December 2014; accepted 23 June 2015.

The increase in urban land and the continuous increment of road network experienced by littoral zones contribute to the loss, degradation and isolation of both terrestrial and aquatic habitats in which amphibians spend the different stages of their life cycle. The aim of this study is to explain the relationship between the characteristics of 17 seasonal ponds located in the Atlantic littoral of Cádiz province (SW Spain), the land uses in their surroundings, the road network, and the diversity of amphibian species. Our results show that amphibian richness is higher in larger ponds with longer hydroperiods, surrounded by forest and scrubland, and away from the nearest road. Roads, and in particular secondary roads, have a great and negative impact on amphibian richness because the shorter the distance between the pond and the road was, the fewer breeding species were found. From the data obtained in this study, we have classified the ponds according to their status of conservation. This classification demonstrates that $94 \%$ of the studied ponds require immediate measures to be taken in order to reduce the negative impact of habitat fragmentation caused by roads. Finally, in order to maintain healthy amphibian populations at the long term, forests and scrublands surrounding ponds must be protected, and connectivity among ponds, as well as with the terrestrial habitats in the vicinity, must be ensured. Preventing amphibians from road kills during their migration movements can be achieved by means of constructing underpasses and tunnels in hot spots.

Key words: amphibian richness; land uses; littoral; roads; seasonal ponds; southern Spain.

Influencia local y paisajística sobre la riqueza de especies de anfibios que se reproducen en charcas temporales del litoral sud-atlántico español. Determinación de impactos. La proliferación de zonas urbanizadas y la expansión de la red de carreteras en zonas costeras contribuyen a la pérdida, degradación y aislamiento de los hábitats tanto terrestres como acuáticos utilizados por los anfibios en las diferentes fases de su ciclo vital. El objetivo de este estudio es explicar la relación entre las características de 17 charcas temporales ubicadas en el litoral atlántico de la provincia de Cádiz (SO de España), los usos del suelo en su entorno, la red de carreteras y la diversidad de especies de anfibios. Nuestros resultados muestran que la riqueza de anfibios es mayor en charcas más grandes y con hidroperiodos más prolongados, rodeadas de zonas forestales y de matorral, y alejadas de las carreteras. Las carreteras, en particular las secundarias, tienen un fuerte impacto 
negativo sobre la riqueza de anfibios, como muestra el hecho de que cuanto menor es la distancia entre la charca y la carretera, menor es el número de especies de anfibios presentes. A partir de los datos obtenidos, clasificamos las charcas de acuerdo a su estado de conservación. Esta clasificación demuestra que el $94 \%$ de las charcas estudiadas requiere la toma inmediata de medidas con el fin de reducir el impacto negativo de la fragmentación del hábitat causada por las carreteras. Por último, para mantener poblaciones de anfibios saludables a largo plazo, es preciso proteger los bosques y zonas de matorral del entorno de las charcas, así como la conectividad entre charcas y con el medio terrestre cercano. La construcción de túneles y pasos subterráneos en puntos negros de atropello puede servir para prevenir la mortalidad de anfibios en las carreteras.

Key words: carreteras; charcas estacionales; España meridional; litoral; riqueza de anfibios; usos del suelo.

The growth of urban and road networks is considered the main factor responsible for habitat loss and fragmentation (Houlahan \& Findlay, 2003; CushMAN, 2006; HAMER \& MCDonnell, 2008). Habitat loss and fragmentation have been described as the main threats to amphibian populations (STUART et al., 2004; BEEBEE \& Griffiths, 2005; Cushman, 2006; Fahrig \& RYTWINSKY, 2009). Habitat fragmentation caused by the road network has negative effects on amphibian persistence. Roads decrease dispersal (DEMAYNAdiER \& Hunter, 2000), increase direct mortality by run over (CARR \& FAHRIG, 2001) and reduce genetic diversity (REH \& SEITZ, 1990).

According to the classification made by the Conservation Measures Partnership and the IUCN Species Survival Commission (SALAFSKY et al., 2008), residential and commercial development poses the highest threat to biodiversity, whereas transportation and service corridors are in fourth position. Residential development and transportation are closely linked to each other, since urban growth requires of building new roads. At the same time, these new roads lead to the transformation and alteration of the surrounding habitat
(Colino Rabanal, 2011).

On the coast of Spain, starting in mid$20^{\text {th }}$ century until the beginning of the $21^{\text {st }}$ century, the surface occupied by urban areas increased due to the success of a model of dispersion of urban areas with a low density of buildings in residential zones, which was accompanied by an increase in the use of private vehicles. This new model became a new concept of life, which quickly spread out to littoral areas still inhabited to that date and ended up occupying a large extension of land (MATA Olmo, 2011).

Nowadays, around 25 million people reside in the coastal areas of Spain, and this population becomes three times larger during the summer season; consequently, and in order to facilitate the movements of people, the transportation network has experienced a proportional growth. In particular, alongside the Atlantic shoreline of Cádiz province, urban areas and road infrastructures have increased a 355\% over the last 50 years, resulting in changes of the land use (Jordán López et al., 2008), habitat fragmentation, and loss of coastal wetlands that were normally used by amphibians as breeding sites (REQues 
RoDRíGuez, 2005).

One of the main types of habitat used by amphibians for breeding in the south of Spain are Mediterranean temporary ponds. This type of ponds was designated as a priority habitat of community interest by the European Union (code 3170) according to the Directive 92/43/EEC of 21 May 1992, and a special area of conservation in Spain (according to Annex 1 of the Royal Decree 1193/1998). Likewise, Convention on Wetlands of International Importance, known as Ramsar Convention, adopted in 2002 resolution VIII.33 on temporary pools, recognizing that temporary ponds of all climatic regions contribute to the maintenance of global biological diversity. However, despite the regulation available protecting temporary ponds and due to the difficulty of perception by the general public and the shortage of scientific inventories and studies, the rate of disappearance of temporary ponds is not decreasing (GARCía de Lomas et al., 2004).

Due to the fact that most temporary ponds located alongside the Atlantic shoreline of Cádiz province are close to urban and residential areas, as well as their short distance to the road network, this study aims to test the cause-effect relationship existing between the richness of amphibians species living in these Mediterranean temporary ponds, the characteristics of the ponds and the land use in their watershed. The results obtained in this study allowed us to classify the different

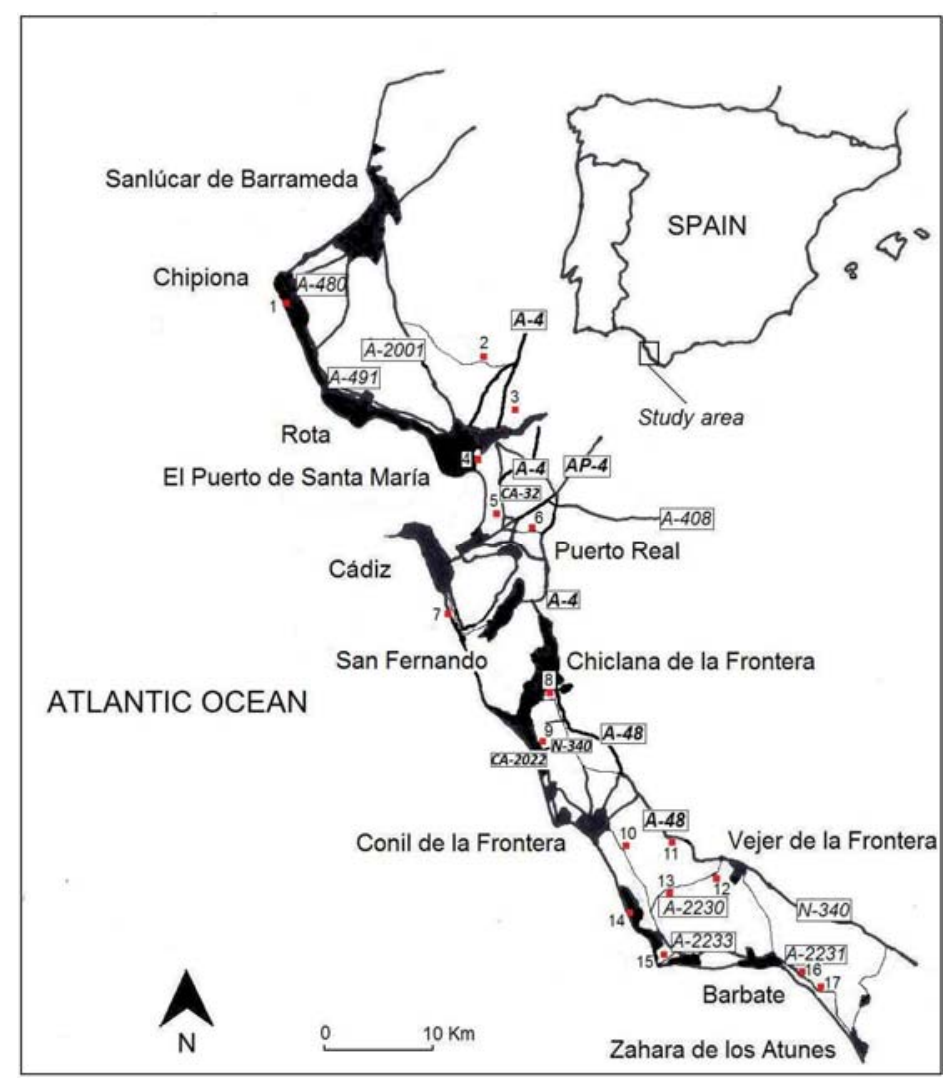

Figure 1: Location of the study area within Spain and map of the study area showing urban areas in black, and major roads represented by a black line. The 17 ponds are identified with red marks (visible only in the online version of the article) and numbers. For pond number identification, refer to Table 2. 
wetlands according to their conservation status and design different management strategies with the aim of preserving them at the medium and long terms (see also OertLi et al., 2002).

\section{Materials ANd Methods}

\section{Study area}

The study area is located in the southwest coast of Spain, facing the Atlantic Ocean, between La Punta del Perro $\left(36^{\circ} 44^{\prime} \mathrm{N}, 6^{\circ} 28^{\prime} \mathrm{W}\right)$ in the municipality of Chipiona, and the mouth of the Cachón del Concho stream $\left(36^{\circ} 9^{\prime} \mathrm{N}, 5^{\circ} 52^{\prime} \mathrm{W}\right)$ in the municipality of Barbate. It is considered as one of the three biogeographic regions within Cádiz Province, named either "littoral" (Busack \& JAKsić, 1982) or "coastal plains and Atlantic countryside" (Gutiérrez Mas et al., 1991; Mateo et al., 2003).

The climate is Mediterranean type with Oceanic influence (CAPel Molina, 2000), with dry and hot summers, mild winters and maximum rainfall at the end of autumn and beginning of winter. The potential vegetation belongs to the Mediterranean Region, Gaditan-Algarvian Subprovince, Gaditan-Coastal Onubensean Sector (Bejarano Palma, 1997). The vegetation should be dominated by cork oak woodland on coastal sand dunes (OleoQuercetum suberis S.), but due to human intervention this vegetation has been replaced by agricultural crops since ancient times (Mateo et al., 2003). At present, the landscape is very open, with extensive cultivation of winter cereals, mainly wheat, and irrigated crops of cotton, and isolated stone pine woodlands (Pinus pinea L.) of different sizes with junipers (Juniperus sp.) as the understorey. These pine plantations are the result of land management practices carried out in order to stabilize the dunes along the coast since the early $20^{\text {th }}$ century (Cueto Állvarez De SoTOMAYOR, 2001; BoHórquez et al., 2012). The salt marsh areas are covered by succulent sub-shrub communities (Arthrocnemun macrostachyum, Suaeda vera and Sarcocornia sp.) (GARcía de Lomas et al., 2008).

Temporary ponds occur throughout the area on sandy or muddy soils, occupying shallow depressions. The functioning of these ponds is closely related to the hydrologic fluctuations of the water table, filling during the autumnal rains and drying in late spring.

Within the area of study there are 10 urban sites and residential areas, all linked by a dense road network (Fig. 1). All main roads run parallel to the coast and are A491 from Chipiona to Cádiz Bay, A-48 from Chiclana de la Frontera to Vejer de la Frontera crossroad, and N-340 from Vejer crossroad to Barbate. A series of secondary roads, perpendicular to the coast, connect these main roads with the coastline.

\section{Data collection}

Amphibian larvae were sampled monthly in 17 seasonal ponds during three consecutive flooding periods between autumn 2006 and summer 2009. The sampling effort was proportional to the pond's surface. A hand-extensible 2-mm meshednet, triangle shaped, was used. Several dip -net hauls were carried out in 5-minute periods in each microhabitat within the largest ponds. Captured larvae were released back to their ponds of origin right 
Table 1: Variables considered at microhabitat and macro-habitat scales to determine their consequences on amphibian richness.

\begin{tabular}{|c|c|c|c|}
\hline Scale & Name (Abbreviation) & Unit & Description \\
\hline \multirow[t]{3}{*}{ Microhabitat } & Surface of body water (S) & $\mathrm{m}^{2}$ & \\
\hline & Maximum depth (D) & $\mathrm{m}$ & \\
\hline & Hydroperiod (HD) & months & \\
\hline \multirow[t]{6}{*}{ Macrohabitat } & $\begin{array}{l}\text { Degree of urbanisation } \\
\text { (DU) }\end{array}$ & $\%$ & $\begin{array}{l}\text { Percentage of the surrounding land covered by } \\
\text { urban or suburban infrastructures }\end{array}$ \\
\hline & $\begin{array}{l}\text { Pastureland and agricul- } \\
\text { tural land (PA) }\end{array}$ & $\%$ & $\begin{array}{l}\text { Percentage of the surrounding land covered by } \\
\text { pastureland and agricultural land. }\end{array}$ \\
\hline & Scrubland and trees (ST) & $\%$ & $\begin{array}{l}\text { Percentage of the surrounding land covered by } \\
\text { scrubland and trees. }\end{array}$ \\
\hline & $\begin{array}{l}\text { Landscape heterogeneity } \\
\text { in the watershed (LH) }\end{array}$ & Categorical & $\begin{array}{l}\text { Categories (0-4), from a single type of land use } \\
\text { to more than four types of land use. Land use } \\
\text { types considered were: pastureland, scrub- } \\
\text { land, the mixture of both, association between } \\
\text { conifer and leafy trees, association between } \\
\text { scrubland and trees, farmland (dryland and } \\
\text { irrigated land) and sands and dunes. Urban } \\
\text { was not considered. }\end{array}$ \\
\hline & Road density (RD) & $\mathrm{km} / 100$ km² & $\begin{array}{l}\text { Kilometres of road per } 100 \text { square kilometres } \\
\text { of area studied around the pond (radius } 1130 \\
\mathrm{~m} \text { ). }\end{array}$ \\
\hline & $\begin{array}{l}\text { Distance to the closest } \\
\text { road (DR) }\end{array}$ & $\mathrm{m}$ & \\
\hline
\end{tabular}

after being sampled. Additionally, visual inspections were conducted in order to locate eggs in accordance to ScotT \& WoodwARD (1994). The species' richness of each pond was calculated as the sum of all species that were detected in the pond at least once during the different sampling campaigns.

We gathered for each location the main environmental variables capable to impact on the richness of amphibian species at two different scales: microhabitat (within pond) and macrohabitat (1130 $\mathrm{m}$ around sampling site, which is equivalent to an area of $4 \mathrm{~km}^{2}$ ). This surface of $4 \mathrm{~km}^{2}$ corresponds to the terrestrial surface needed by European amphibians during reproduc- tion (ACEMAV, 2003). Table 1 shows the variables considered at each scale. At the macrohabitat scale, the environmental variables were related to the landscape in which the ponds are located. The land-use coverage was determined by means of the digital map of land uses of the Sistema de Información Geográfico Agrario (UTM/ ETRS89 Ellipsoid projection; Ministerio de Agricultura, Alimentación y Medio Ambiente, 2011a) and digital aerial photographs of the Visor del Sistema de Información Geográfico de Parcelas Agrícolas (Ministerio de Agricultura, Alimentación y Medio Ambiente, 2011b). Data were calculated as cover percentage of each land use in the accessible part of 
TORRES ET AL.

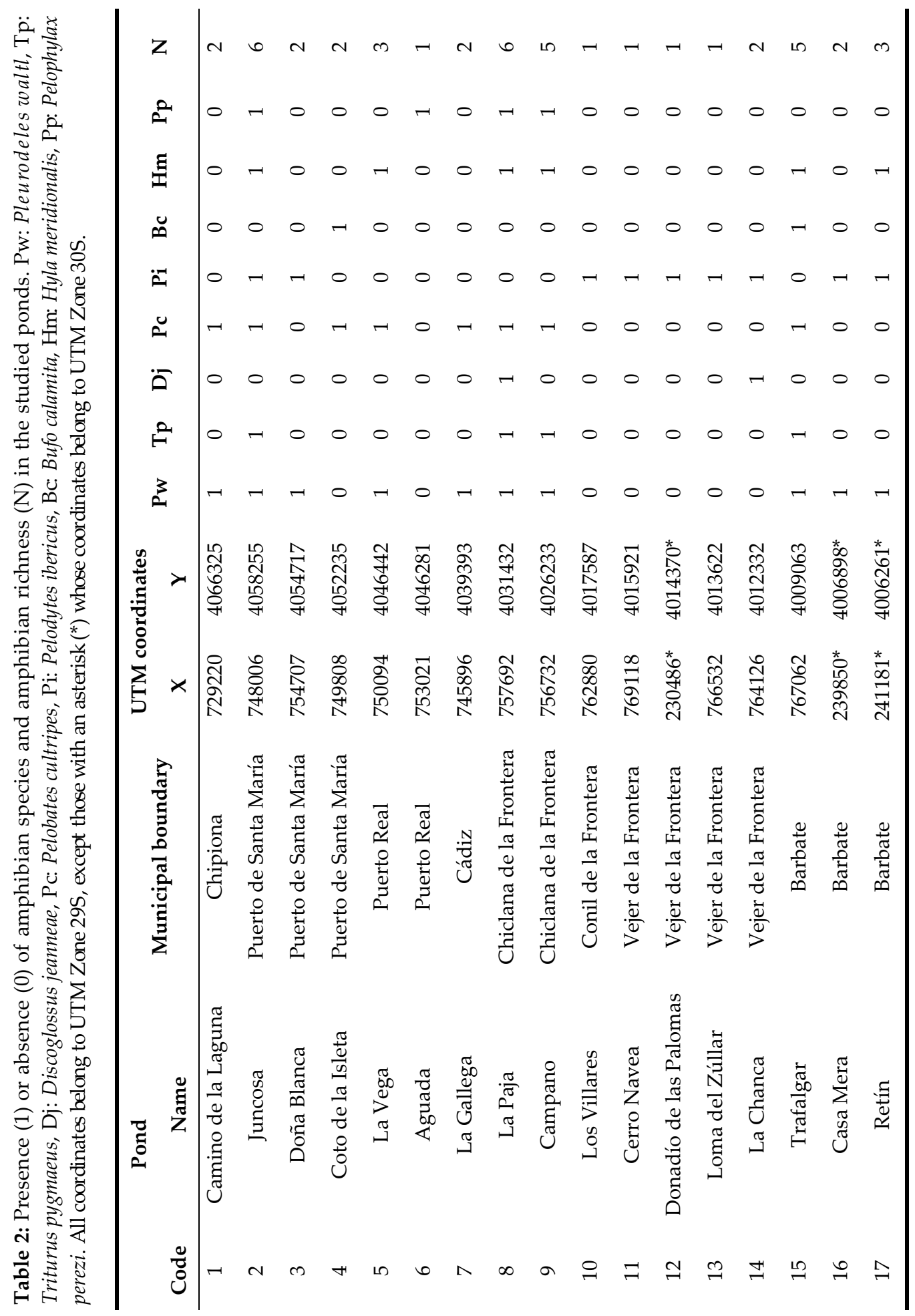


the chosen surface around each pond. Thus, in cases where the ponds were located less than $1130 \mathrm{~m}$ away from the sea, the area covered by the sea was ruled out from the analysis. Sampling ponds were at least $2.3 \mathrm{~km}$ apart to avoid overlap.

To determine the urban impact on amphibian richness, we calculated an anthropogenic index named "degree of urbanization", which measures the percentage of built-up area (SCHER \& THIÈrY, 2005). To ascertain the effect of roads on amphibian richness, we measured road density and the minimum distance from the centre of the pond to the closest road.

\section{Statistical analysis}

A Principal Component Analysis (PCA) was applied in order to understand the relationship among selected variables, using the varimax normalized rotation (Guisande González et al., 2006).

The relationship between amphibian richness and the extracted principal factors, as independent variables, was analysed by means of a multiple regression. GARCíA-MuÑoz et al. (2010) successfully used this methodology in a previous research conducted in the southeast of the Iberian Peninsula in order to establish the relationship among the characteristics of the wetlands, the Mediterranean landscapes, and the richness of amphibian species. Likewise, following the methods used in that study, a scatter plot with significant factors was created in order to show the distribution of wetlands in the area.

To confirm the effect of roads on the richness of amphibians, a non-parametric Spearman correlation between distance to the closest road and amphibian richness per pond was performed.

Statistical analysis was performed using SPSS 19 for Windows software (PÉREZ López, 2005). A significance level of 0.05 was considered.

\section{Results}

Two species of urodeles, the sharpribbed newt (Pleurodeles walt Michahelles, 1830) and the pygmy marbled newt (Triturus pygmaeus Wolterstorff, 1905), and six anuran species, the Spanish painted frog (Discoglossus jeanneae Busack, 1986), the Western spadefoot toad (Pelobates cultripes Cuvier, 1829), the Iberian parsley frog (Pelodytes ibericus Sánchez-Herráiz, Barbadillo, Machordom \& Sanchiz, 2000), the natterjack toad (Bufo calamita Laurenti, 1768), the stripeless treefrog (Hyla meridionalis Boettger, 1874) and the Iberian green frog (Pelophylax perezi López Seoane, 1885) bred at the studied wetlands (Table 2). This amphibian diversity represented $80 \%$ of the species known at the regional scale (Blanco Villero et al., 1995). Pond occupancy ranged from $59 \%$ for $P$. waltl to $12 \%$ for $D$. jeanneae and $B$. calamita. Mean $( \pm \mathrm{SD})$ species richness was $2.6 \pm 1.35$, ranging from one to six species per pond. Only two wetlands, La Juncosa and La Paja, had the highest number of breeding species.

The results of all environmental variables retrieved from each pond are shown in Table 3. Mean distance between ponds and closest roads was $211.24 \mathrm{~m}$, ranging from 5 to $1820 \mathrm{~m}$. Secondary roads are the closest roads in fifteen ponds, whereas only in two ponds (La Gallega and Doña Blanca) the nearest roads are highways.

The first three principal components of 
Table 3: Values per pond of the variables selected for the Principal Component analysis. For abbreviations and explanation of the variables, refer to Table 1.

\begin{tabular}{lccccccccc}
\hline Pond & S & D & HD & DU & PA & ST & LH & RD & DR \\
\hline Camino La Laguna & 175 & 0.4 & 7 & 34.96 & 39.22 & 11.70 & 1 & 0.86 & 30.00 \\
Juncosa & 81000 & 2.0 & 12 & 8.65 & 66.02 & 0.91 & 2 & 0.75 & 129.21 \\
Doña Blanca & 5850 & 0.6 & 8 & 0.00 & 82.97 & 17.03 & 0 & 0.30 & 1820.00 \\
Coto de la Isleta & 20000 & 0.4 & 4 & 36.50 & 9.80 & 10.05 & 2 & 1.10 & 42.00 \\
La Vega & 1200 & 0.5 & 7 & 46.32 & 15.23 & 23.94 & 4 & 1.79 & 73.60 \\
Aguada & 4306 & 0.4 & 9 & 55.10 & 21.02 & 10.37 & 1 & 1.77 & 38.00 \\
La Gallega & 700 & 0.4 & 7 & 29.20 & 10.00 & 17.53 & 1 & 2.30 & 20.00 \\
La Paja & 326000 & 1.8 & 10 & 26.90 & 20.09 & 26.20 & 2 & 1.49 & 300.00 \\
Campano & 50000 & 2.0 & 12 & 8.23 & 16.20 & 55.64 & 2 & 1.13 & 422.00 \\
Los Villares & 195 & 0.4 & 5 & 6.15 & 81.18 & 8.80 & 0 & 0.60 & 5.00 \\
Cerro Navea & 30 & 0.1 & 4 & 9.90 & 90.20 & 7.72 & 0 & 1.11 & 115.00 \\
Donadío de las Palomas & 96 & 0.1 & 4 & 5.22 & 80.54 & 13.38 & 1 & 0.58 & 51.20 \\
Loma del Zúllar & 60 & 0.2 & 6 & 0.00 & 98.60 & 0.00 & 0 & 0.72 & 7.00 \\
La Chanca & 1350 & 0.3 & 5 & 20.51 & 47.00 & 17.38 & 2 & 1.69 & 20.00 \\
Trafalgar & 2000 & 0.5 & 8 & 9.34 & 0.00 & 45.87 & 2 & 0,80 & 430.00 \\
Casa Mera & 350 & 0.3 & 5 & 7.46 & 67.96 & 0.00 & 1 & 1.27 & 48.00 \\
Retín & 25600 & 0.6 & 7 & 2.53 & 90.40 & 7.57 & 1 & 0.72 & 40.00 \\
\hline
\end{tabular}

Table 4: Percent of explained variance and scores of the environmental variables used in the Principal Component Analysis. The main variables relative to each axis are indicated in bold characters. For variable abbreviation legend, refer to Table 1 .

\begin{tabular}{lccc}
\hline & PC1 & PC2 & PC3 \\
\hline Variance (\%) & 33.78 & 27.01 & 17.86 \\
S & 0.092 & $\mathbf{0 . 8 5 0}$ & -0.108 \\
D & 0.033 & $\mathbf{0 . 9 4 0}$ & 0.234 \\
HD & 0.102 & $\mathbf{0 . 8 0 3}$ & 0.376 \\
DU & $\mathbf{0 . 8 6 1}$ & -0.047 & -0.142 \\
PA & $\mathbf{- 0 . 8 5 9}$ & -0.166 & -0.381 \\
ST & 0.338 & 0.238 & $\mathbf{0 . 8 0 7}$ \\
LH & $\mathbf{0 . 7 2 9}$ & 0.297 & 0.204 \\
RD & $\mathbf{0 . 8 4 2}$ & -0.010 & -0.192 \\
DR & -0.430 & 0.080 & $\mathbf{0 . 7 1 0}$ \\
\hline
\end{tabular}

the PCA explained $78.65 \%$ of the total environmental variance amongst ponds (Table 4). The first principal component (PC1) was mainly defined by positive cor- relations with the degree of urbanisation, landscape heterogeneity in the watershed, and density of roads, and a negative correlation with the percentage of the ground covered by pastureland and agricultural land. This axis was interpreted as a gradient from more urban habitats with greater road density, to more agricultural habitats with less urban land, a more homogeneous landscape and a lower density of roads. The second principal component (PC2) was positively correlated with the percentage of the ground covered by scrubland and trees and the distance to the nearest road. This axis was interpreted as a gradient of quality of terrestrial habitat around the breeding ponds. Finally, the third principal component (PC3) was positively correlated with the surface area and the hydroperiod of ponds. This axis was interpreted as a gradient from larger 
Table 5: Relationships between amphibian richness and pond characteristics analysed by multiple regression with principal components as independent variables. Values in bold indicate significant effects at the level $P<0.05$.

\begin{tabular}{|c|c|c|c|c|c|}
\hline & \multicolumn{2}{|c|}{$\begin{array}{l}\text { Determination } \\
\text { coefficient }\end{array}$} & \multirow{2}{*}{$\begin{array}{c}\text { Std. } \\
\text { coefficient } \\
\text { Beta }\end{array}$} & \multirow[t]{2}{*}{$t$} & \multirow[t]{2}{*}{$\mathbf{P}$} \\
\hline & B & SE & & & \\
\hline Constant & 2.588 & 0.181 & & 14.294 & 0.000 \\
\hline PC1 & 0.319 & 0.187 & 0.192 & 1.711 & 0.111 \\
\hline PC2 & 1.339 & 0.187 & 0.806 & 7.173 & 0.000 \\
\hline PC3 & 0.641 & 0.187 & 0.386 & 3.432 & 0.004 \\
\hline
\end{tabular}

ponds with longer hydroperiods to smaller ponds with more ephemeral inundation. After multiple regression analysis, only PC2 and PC3 showed a statistically significant effect on amphibian richness (Table 5). The scatter plot designed with both significant factors allows us to determine the position of each pond in a twodimensional space (Fig. 2).

Using this two-dimensional space, ponds were classified in four categories: (I) large ponds with long hydroperiod and high quality landscape in the surrounding terrestrial habitat, with only one pond belonging to this category; (II) small water bodies with short hydroperiod and high

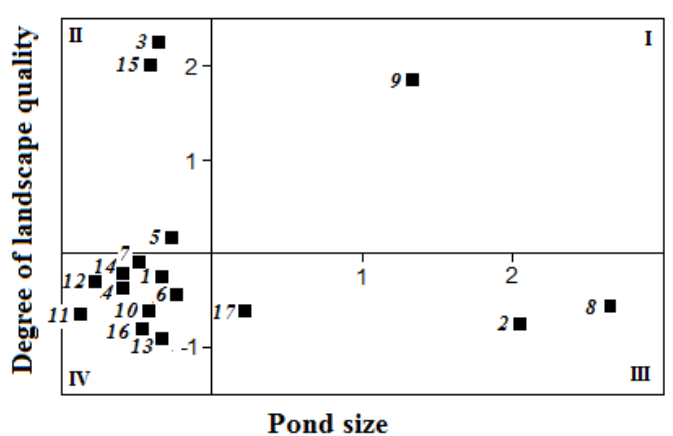

Figure 2: Projection of the ponds in the bidimensional space formed by PC2 (quality of landscape, vertical axis) and PC3 (pond size, horizontal axis). terrestrial habitat quality, with three ponds in this category; (III) large ponds with long hydroperiod and low terrestrial habitat quality, including another three ponds; and (IV) small ponds with short hydroperiod and low terrestrial habitat quality, with most of the ponds $(\mathrm{N}=10)$ located in this category.

Ponds located further away from the closest road showed higher amphibian richness $($ Rho $=0.586 ; P<0.05)$.

\section{Discussion}

The results obtained in this study show that, in the Atlantic littoral of Cádiz province, large temporary ponds with long hydroperiods host the maximum species richness of amphibians. This is consistent with the view that ponds with longer hydroperiods contribute to species richness because opportunities for reproduction are given to species breeding at different times of the year (BEJA \& Alcazar, 2003; Jаков et al., 2003; Weyrauch \& Grubb, 2004). Species found in this study breed from early autumn (e.g. P. waltl and P. cultripes in October, prolonging their reproductive period until spring) to summer (P. perezi). In addition, a more prolonged flooding period allows a longer larval period and consequently a larger size at metamorpho- 
sis (ЈАков et al., 2003), which is known to enhance survival and fecundity (Semlitsch et al., 1988).

At the landscape level, forest and scrubland coverage and road proximity were the most important variables in determining amphibian species richness. Although up to six of the species found in the present study ( $P$. waltl, T. pygmaeus, $P$. cultripes, $P$. ibericus, B. calamita and $P$. pere$z i$ ) are known to live in open areas (GarcíaPARís et al., 2004), the presence of remnant forest patches in agricultural or suburban landscapes provides refuge for some anuran species (KNUTson et al., 1999), as well as overwintering sites for metamorphosed individuals (DEMAynadier \& Hunter, 1999). Consequently, amphibian richness and abundance is often reported to be positively associated with forest cover (Knutson et al., 1999; Houlalan \& FindLAY, 2003; VAN Buskirk, 2005).

Distance to the closest road is a critical variable to explain the richness of amphibians, since we found that the shorter the distance is from the centre of the pond to the nearest road, the fewer species breed in that pond. This is consistent with the opinion that roads have a substantial negative effect on the distribution of amphibian species and on their persistence (Vos \& Chardon, 1998; Carr \& Fahrig, 2001; CoLino-Rabanal \& Lizana, 2012), as both adults (during the reproduction migration) and juveniles (during the dispersal phase) (CARr \& FAHrig, 2001) can be run over by vehicles. Additionally, roads act as barriers for juvenile dispersal (GibBs, 1998), which are excluded from the roadsurrounding area (López, 2001) because of the high level of pollution caused by vehi- cle traffic (gas emission, oil leaks, solid waste, light and noise) (BARrass, 1986; Vos \& Chardon, 1998; Trombulak \& Frissell, 2000; Mazerolle et al., 2005). This barrier effect increases isolation and threatens viability of amphibian populations (Spellerberg, 1998; Cushman, 2006).

Some works point that traffic density would have a higher relative importance than forest cover in the landscape for determining species richness (EIGENBRoD et al., 2008). However, in our study, amphibian richness has not been found to be dependent on the density of roads. This result suggests that the disposition of each road determines a very different potential for fragmentation. Thus, roads close to the ponds, mainly secondary roads, commonly act as barriers between ponds, which results in increased road mortality and the consequent fragmentation of populations. In this study, we have not obtained data on traffic density, which can be crucial to understand the effect of each road. Future field works are therefore necessary to analyse the mortality caused by these roads and relate it to traffic density. Also, future comparisons of movement patterns between species could bring crucial information in order to understand the effect of roads on a particular species, since studies conducted in Central Europe suggest that migration distances differ between them (Kovar et al., 2009), and that more vagile species may be more vulnerable to road mortality than less vagile ones (CARR \& FAHRIG, 2001). An additional problem is that dispersal ability of Iberian amphibians is poorly known (RIBEIRo et al., 2011).

It should also be taken into consideration that the areas adjacent to roads expe- 
rience several types of modifications because of human action (TrombulaK \& FrisSELL, 2000). In the coast of Cádiz province, in particular, land use changes affect areas located up to $1000 \mathrm{~m}$ away from the road. These changes are potentially more intense than those caused by urban areas (JoRDÁn López et al., 2008). All studied ponds except one are located less than $600 \mathrm{~m}$ away from the nearest road, which involves an additional impact on amphibians on top of road-related mortality and habitat fragmentation.

Based on the scatter plot (Fig. 2), the studied ponds were classified into four groups: The pond in category I, Laguna de Campano, has a long hydroperiod and high quality of the surrounding terrestrial habitat. This pond is located in a wellpreserved meadow inside a private property of $8.9 \mathrm{~km}^{2}$. Its catchment has the highest percentage of the ground covered by the mixture of pastureland and scrubland in the study area. The nearest road is in a residential area with a golf course, and constitutes an example of road construction as part of urban development on the coast.

Category II ponds are bodies of water with small size and short hydroperiods, which are located moderately far from the nearest road. Within this group, we find the Trafalgar pond, with five breeding species. This pond is part of a set of interdune ponds, with seasonal character and small dimensions, forming a unique ecosystem on the coast of Cádiz (Reques, 2004) where seven species of amphibians reproduce (Torres et al., 2014). However, the main conservation problem of this pond is that its hydroperiod has decreased due to silting. If, in stead of choosing a single pond, we had considered the sum of the surface of all ponds within the radius of 1130 meters, possibly this set of wetlands located in Trafalgar would have been assigned to category I. This is in agreement with the opinion that a set of ponds of small size has more species and a higher conservation value than a single large pond of the same total area (Oertli et al., 2002).

Category III ponds are large water bodies surrounded by a low quality terrestrial habitat, because they are located in agricultural and pasture (Juncosa and Retín) or in suburban landscapes (La Paja). The Juncosa and La Paja ponds have the highest species richness of all studied ponds. The main problem of conservation of $\mathrm{La}$ Paja is that it is almost completely surrounded by roads (N-340 and Carretera de las Lagunas) that cause death by run over of adult and metamorphic amphibians. Specifically, the Carretera de las Lagunas road crosses the normal migratory path of amphibians from the pond to the adjacent pine forest named Pinar del Hierro (Sánchez García, 2000).

Category IV includes ponds with the lowest richness of amphibians, only one or two breeding species, due to the small size and low landscape quality. This is a heterogeneous group of ponds, but all of them are located on the edge of a road and some of them occur in an agricultural landscape (Los Villares, Cerro Navea, Donadío de las Palomas, Loma del Zúllar and Casa Mera). Pelodytes ibericus was observed to breed in all these ponds, indicating that its adaptability to open areas. The rest of the ponds within this category were located in a sub- 
urban-dominated landscape.

In conclusion, $94 \%$ of ponds in this study (all those included in categories II, III and IV) require specific action plans with the aim to preserve these wetlands and ensure the survival of the species that breed in them. The four ponds with higher amphibian richness suffer habitat fragmentation and isolation due to the road network.

Data from the present study are crucial to understand, within the landscape scale, the importance of taking measures of proven efficiency to minimize the impact of roads over the species' richness in the area of study. To accomplish that, an appropriate planning of the land, as well as local scale mitigation measures (Colino Rabanal, 2011; Colino-Rabanal \& Lizana, 2012), should be established by accurately locating the amphibian paths alongside the different roads during their migratory movements (Colino Rabanal, 2011). Once the exact location of hot spots used by amphibians to cross the roads has been established, the main measures that should be implemented are: (i) construction of underpasses and tunnels and establishment of appropriate buffer zones alongside the roads (Iglesias Merchán, 2007; MartínezFreiría \& BRITO, 2012), a measure for instance necessary to connect La Paja with Pinar del Hierro; (ii) construction of fences or walls to impede the access of individuals to the road (Iglesias Merchán, 2007; Martínez-Freiría \& Brito, 2012); and (iii) connection of populations by means of natural corridors, building new ponds that allow amphibian dispersion and connection, aiming to connect meta-populations. All these measures should be carried out in parallel to detailed studies to assess their effectiveness, as well as environmental awareness campaigns about this conservation issue (MARTínez-Freiría \& BRITO, 2012).

\section{Acknowledgement}

We acknowledge the comments by three anonymous reviewers that greatly improved the manuscript. Collecting permits were provided by Consejería de Medio Ambiente y Ordenación del Territorio of the Junta de Andalucía.

\section{REFERENCES}

ACEMAV (2003). Les Amphibiens de France, Belgique et Luxembourg. Biotope, Mèze, France.

BARRASS, A.N. (1986). The effects of highway noise on the phonotactic and associated reproductive behaviour of selected anurans. Dissertation Abstracts International B 46: 2609.

Beebee, T.J.C. \& Griffiths, R.A. (2005). The amphibian decline crisis: A watershed for conservation biology? Biological Conservation 125: 271-285.

Beja, P. \& Alcazar, R. (2003). Conservation of Mediterranean temporary ponds under agricultural intensification: an evaluation using amphibians. Biological Conservation 114: 317-326.

Bejarano Palma, R. (1997). Vegetación y Paisaje en la Costa Atlántica de Andalucía. Universidad de Sevilla, Seville, Spain.

Blanco Villero, J.M.; Márquez Aguilar, A.; Sáez Bolaño, J.; Sánchez García, B. \& Sánchez García, I. (1995). Anfibios y Reptiles de la Provincia de Cádiz. Consejería de Medio Ambiente, Junta de Andalucía, Jerez de la Frontera, Spain.

Bohórquez, M.; Jiménez Mejías, P.; Esquivias, R. \& Martín Bravo, S. (2012). Notas corológicas sobre flora del litoral gaditano. Acta Botanica Malacitana 37: 230-233.

BusacK, S.D. \& JAKsIĆ, F.M. (1982). Ecological 
and historical correlates of Iberian herpetofaunal diversity: an analysis at regional and local levels. Journal of Biogeography 9: 289-302.

Capel Molina, J.J. (2000). El Clima de la Península Ibérica. Ariel, Barcelona, Spain.

CARr, L.W. \& FAHrig, L. (2001). Effect of road traffic on two amphibian species of different vagility. Conservation Biology 15: 10711078.

Colino Rabanal, V.J. (2011). Contribuciones al Análisis de Mortalidad de Vertebrados en Carreteras. Ph.D. Dissertation, Universidad de Salamanca, Salamanca, Spain.

Colino-Rabanal, V.J. \& Lizana, M. (2012). Herpetofauna and roads: a review. Basic and Applied Herpetology 26: 5-31.

Cueto Álvarez de Sotomayor, M. (2001). Ordenación de pinares de pino piñonero en la provincia de Cádiz. Cuadernos de la Sociedad Española de Ciencias Forestales 11: 125134.

Cushman, S.A. (2006). Effects of habitat loss and fragmentation on amphibians: A review and prospectus. Biological Conservation 128: 231-240.

deMaynadier, P.G. \& Hunter, M.L. JR. (1999). Forest canopy closure and juvenile emigration by pool-breeding amphibians in Maine. The Journal of Wildlife Management 63: 441450.

deMaynadier, P.G. \& Hunter, M.L. JR. (2000). Road effects on amphibian movements in a forested landscape. Natural Areas Journal 20: 56-65.

Eigenbrod, F; Hecnar, S.J. \& Fahrig, L. (2008). The relative effects of road traffic and forest cover on anuran populations. Biological Conservation 141: 35-46.

FAhrig, L. \& RYtwinski, T. (2009). Effects of roads on animal abundance: an empirical review and synthesis. Ecology and Society 14: 21.

García De Lomas, J.; García, C.M. \& Canca, I. (2004). Caracterización y fenología de las lagunas temporales del pinar de La Algaida
(Puerto Real, Cádiz). Revista de la Sociedad Gaditana de Historia Natural 4: 105-124.

García De lomas, J.; García, C.M. \& Álvarez, O. (2008). Vegetación de las marismas de Aletas-Cetina (Puerto Real). Identificación de hábitats de interés comunitario y estimaciones preliminares de posibles efectos de su inundación. Revista de la Sociedad Gaditana de Historia Natural 5: 9-37.

García-Muñoz, E.; Gilbert, J.D.; Parra, G. \& Guerrero, F. (2010). Wetlands classification for amphibian conservation in Mediterranean landscapes. Biodiversity and Conservation 19: 901-911.

García-París, M.; Montori, A. \& Herrero, P. (2004). Amphibia, Lissamphibia. Series: Fauna Ibérica, vol. 24 (M.A. Ramos, coord.). Museo Nacional de Ciencias Naturales, CSIC, Madrid, Spain.

Gıввs, J.P. (1998). Amphibian movements in reponse to forest edges, roads, and streambeds in southern New England. The Journal of Wildlife Management 62: 584-589.

Guisande González, C.; Barreiro Felpeto, A.; Maneiro Estraviz, I.; Riveiro Alarcón, I.; Vergara Castaño, A.R. \& Vaamonde Liste, A. (2006). Tratamiento de Datos. Díaz de Santos, Madrid, Spain.

Gutiérrez Mas, J.M.; Martín, A.; Domínguez, S. \& Moral, J.P. (1991). Introducción a la Geología de la Provincia de Cádiz. Universidad de Cádiz, Cádiz, Spain.

Hamer, A.J. \& McDonnell, M.J. (2008). Amphibian ecology and conservation in the urbanising world: A review. Biological Conservation 141: 2432-2449.

Houlahan, J.E. \& Findlay, C.S. (2003). The effects of adjacent land use on wetland amphibian species richness and community composition. Canadian Journal of Fisheries and Aquatic Sciences 60: 1078-1094.

Iglesias Merchán, C. (2007). Permeabilidad faunística en infraestruturas de transporte: necesidad de reconsiderar algunos criterios en la evaluación de impacto ambiental y propuesta de definiciones, In M.A. Ca- 
sermeiro Martínez, A.P. Espluga González de la Peña, L.A. Desdentado Gómez, M. Díaz Martín, L.G. García Montero, I. Sobrini Sagaseta de Ilurdoz \& M. Andrés Abellán (eds.) Evaluación de Impacto Ambiental en España: Nuevas Perspectivas (Actas del IV Congreso Nacional de Evaluación de Impacto Ambiental. IV Coneia). Asociación Española de Evaluación de Impacto Ambiental, Madrid, Spain, pp. 197-205.

Jаков, C.; Poizat, G.; Veith, M.; Seitz, A. \& Crivelli, A.J. (2003). Breeding phenology and larval distribution of amphibians in a Mediterranean pond network with unpredictable hydrology. Hydrobiologia 499: 5161.

Jordán López, A.; Martínez-Zavala, L.; González Peñaloza, F.A. \& Bellifante Crocci, N. (2008). Cambios de Uso del Suelo en la Costa de la Provincia de Cádiz durante la Segunda Mitad del Siglo XX (1956-2003). Series: Documentos de Trabajo, vol. T2008/02. Centro de Estudios Andaluces, Junta de Andalucía, Sevilla, Spain.

Knutson, M.G.; Sauer, J.R.; Olsen, D.A.; Mossman, M.J.; Hemesath, L.M. \& Lannoo, M.J. (1999). Effects of landscape composition and wetland fragmentation on frog and toad abundance and species richness in Iowa and Wisconsin, U.S.A. Conservation Biology 13: 1437-1446.

Kovar, R.; Brabec, M.; Vita, R. \& Bocek, R. (2009). Spring migration distances of some Central European amphibian species. Amphibia-Reptilia 30: 367-378.

López, C. (2001). El impacto de las carreteras en las poblaciones de anfibios. Quercus 183: 14 $-18$.

Martínez-Freiría, F. \& Brito, J.C. (2012). Quantification of road mortality for amphibians and reptiles in Hoces del Alto Ebro y Rudrón Natural Park in 2005. Basic and Applied Herpetology 26: 33-42.

Mata Olmo, R. (2011). Urbanización reciente y cambios paisajísticos en España. Por una nueva cultura del territorio y un urbanismo renovado, In J.M. Jurado Almonte (coord.) Ordenación del Territorio y Urbanismo: Conflictos y Oportunidades. Universidad Internacional de Andalucía, Seville, Spain, pp. 2149.

Mateo, J.A.; Pleguezuelos, J.M.; Fahd, S.; Geniez, P. \& Martínez-Medina, F.J. (2003). Los Anfibios, los Reptiles y el Estrecho de Gibraltar. Un Ensayo sobre la Herpetofauna de Ceuta y su Entorno. Instituto de Estudios Ceutíes, Ceuta, Spain.

Mazerolle, M.J.; Huot, M. \& Gravel, M. (2005). Behavior of amphibians on the road in response to car traffic. Herpetologica 61: 380-388.

Ministerio de Agricultura, Alimentación y Medio Ambiente (2011a). Sistema de Información Geográfica de Datos Agrarios (SIGA). Ministerio de Agricultura, Alimentación y Medio Ambiente, Madrid, Spain. Available at http://sig.marm.es/siga/. Retrieved on 01/17/2015.

Ministerio de Agricultura, Alimentación y Medio Ambiente (2011b). Sistema de Información Geográfica de Parcelas Agrícolas (SIGPAC). Ministerio de Agricultura, Alimentación y Medio Ambiente, Madrid, Spain. Available at http://sigpac.magrama.es/fega/ visor/. Retrieved on 01/17/2015.

Oertli, B.; Joye, D.A.; Castella, E.; Juge, R.; Cambin, D. \& Lachavanne, J.-B. (2002). Does size matter? The relationship between pond area and biodiversity. Biological Conservation 104: 59-70.

Pérez López, C. (2005). Métodos Estadísticos Avanzados con SPSS. Thomson, Madrid, Spain.

ReH, W. \& Seitz, A. (1990). The influence of land use on the genetic structure of populations of the common frog Rana temporaria. Biological Conservation 54: 239-249.

Reques, R. (2004). Hábitats reproductivos de anfibios en la provincia de Cádiz: perspectivas para su conservación. Revista de la Sociedad Gaditana de Historia Natural 4: 83-103.

Reques Rodríguez, R. (2005). Conservación de la Biodiversidad en los Humedales de Andalucía, 
$2^{\text {nd }} e d$. Consejería de Medio Ambiente, Junta de Andalucía, Seville, Spain.

Ribeiro, R.; Carretero, M.A.; Sillero, N.; Alarcos, G.; Ortiz-Santaliestra, M.; LizaNA, M. \& Llorente, G.A. (2011). The pond network: can structural connectivity reflect on (amphibian) biodiversity patterns? Landscape Ecology 26: 673-682.

SAlafsky, N.; Salzer, D.; Stattersfield, A.J.; Hilton-Taylor, C; Neugarten, R.; Butchart, S.H.M.; Collen, B.; Cox, N; MasTER, L.L.; O'CONNOR, S. \& Wilkie, D. (2008). A standard lexicon for biodiversity conservation: unified classifications of threats and actions. Conservation Biology 22: 897-911.

Sánchez García, I. (2000). Flora Amenazada del Litoral Gaditano. Consejería de Medio Ambiente de la Junta de Andalucía y Diputación de Cádiz. Jerez de la Frontera, Spain.

Scher, O. \& ThiÈry, A. (2005). Odonata, amphibia and environmental characteristics in motorway stormwater retention ponds (Southern France). Hydrobiologia 551: 237251.

ScotT, N.J. JR. \& Woodward, B.D. (1994). Surveys at breeding sites, In W.R. Heyer, M.A. Donelly, R.W. McDiarmid, L.-A.C. Hayeck \& M.S. Foster (eds.) Measuring and Monitoring Biological Diversity. Standard Methods for Amphibians. Smithsonian Institution Press, Washington, DC, USA, pp. 118-125.

Semlitsch, R.D.; Scott, D.E. \& Pechmann, J.H.K. (1988). Time and size at metamor- phosis related to adult fitness in Ambystoma talpoideum. Ecology 69: 184-192.

SPellerberg, I.F. (1998): Ecological effects of roads and traffic: a literature review. Global Ecology and Biogeography Letters 7: 317-333.

Stuart, S.N.; Chanson, J.S.; Cox, N.A.; Young, B.E.; Rodrigues, A.S.L.; Fischman, D.L. \& WALter, R.W. (2004). Status and trends of amphibian declines and extinctions worldwide. Science 306: 1783-1786.

Torres, J.M.; Hernández, I. \& Reques, R. (2014). Anfibios del litoral atlántico de la provincia de Cádiz: distribución reproductiva, estado de conservación y localidades de mayor interés para su conservación. Revista de la Sociedad Gaditana de Historia Natural 8: 21-30.

TrombulaK, S.C. \& Frissell, C.A. (2000): Review of ecological effects of roads on terrestrial and aquatic communities. Conservation Biology 14: 18-30.

VAN Buskirk, J. (2005). Local and landscape influence on amphibian occurrence and abundance. Ecology 86: 1936-1947.

Vos, C.C. \& Chardon, J.P. (1998). Effects of habitat fragmentation and road density on the distribution pattern of the moor frog Rana arvalis. Journal of Applied Ecology 35: 44-56.

Weyrauch, S.L. \& Grubb, T.C. Jr. (2004). Patch and landscape characteristics associated with the distribution of woodland amphibians in an agricultural fragmented landscape: an information-theoretic approach. Biological Conservation 115: 443-450. 